\title{
PENGARUH RELIGIUSITAS DAN KEGIATAN SPIRITUAL TERHADAP PERSEPSI TINGKAT KEAMANAN DI INDONESIA
}

\author{
Zaki Abdullah, ${ }^{\mathrm{a}, 1, *}$, Hasse Jubba ${ }^{\mathrm{b}, 2}$ \\ ${ }^{a}$ Universitas Gadjah Mada, Yogyakarta, 55281, Indonesia \\ ${ }^{b}$ Universitas Muhammadiyah, Yogyakarta, 55183, Indonesia \\ ${ }^{1}$ zaki.abdullah@mail.ugm.ac.id*; ${ }^{2}$ hasse@umy.ac.id
}

ARTICLE INFO

Article history:

Received : 2019-12-14

Revised : 2020-01-24

Accepted : 2020-06-01

Keywords:

Religion

Security

Spiritual Activity

Kata Kunci:

Agama

Keamanan

Kegiatan Spiritual

\section{ABSTRACT}

Both religiosity and spiritual activities could improve security perceptions by reducing crime rates in Indonesia. However, this did not apply to minorities because of the possibility of religious discrimination. This study intended to determine the influence of religiosity and spiritual activities on the security perceptions of religious adherents in Indonesia, namely Islam, Protestantism, Catholicism, Hinduism and Buddhism using secondary data obtained from the Indonesian Family Life Survey of 32,466 individuals. The finding revealed that religiosity had a positive and significant effect on the sense of security of all adherents except Buddhist followers. Meanwhile, spiritual activities had a positive effect on security of adherents of Islam and Hinduism. In contrast, it negatively influenced Protestant, Catholic and Buddhist followers, since terrorism and discrimination against the worship places were frequently occured. Therefore, it was concluded that religiosity had a positive effect on security of the followers of the majority religions; however, it negatively affected to the followers of minority religion. It meant that being the followers of religion majority was still dangerous for the followers of religion minority. This evidenced that there were still lack of religious tolerance in Indonesia.

\section{ABSTRAK}

Religiusitas dan kegiatan spiritual secara bersama-sama dapat meningkatkan persepsi keamanan dengan mengurangi tingkat kriminalitas di Indonesia, namun hal tersebut tidak berlaku bagi kaum minoritas karena kemungkinan adanya diskriminasi agama. Penelitian ini bertujuan untuk mengetahui pengaruh religiusitas dan kegiatan spiritual terhadap persepsi keamanan para penganut agama di Indonesia yakni Islam, Protestan, Katolik, Hindu dan Budha menggunakan data sekunder yang diperoleh dari Indonesian Family Life Survey sebanyak 32,466 individu. Hasil menunjukkan bahwa religiusitas berpengaruh positif dan signifikan terhadap rasa aman setiap penganut agama kecuali penganut agama Budha, sedangkan kegiatan spiritual memberikan pengaruh positif terhadap rasa aman penganut agama Islam dan Hindu namun memberikan pengaruh negatif bagi penganut agama Protestan, Katolik dan Budha karena kerapkali terjadi fenomena terorisme dan diskriminasi terhadap keberadaan rumah ibadah. Sehingga dapat disimpulkan bahwa religiusitas berpengaruh positif terhadap rasa aman penganut agama mayoritas, namun berpengaruh negatif terhadap rasa aman penganut minoritas. Artinya, menjadi religius baik bagi mayoritas tetapi masih berbahaya bagi kaum minoritas. Hal ini membuktikan masih kurangnya toleransi keberagamaan di Indonesia. 


\section{Pendahuluan}

Kerukunan masyarakat di Indonesia tidak hanya dipengaruhi oleh norma sosial yang berlaku, namun juga dipengaruhi oleh kondisi sosial keagamaan. Ajaran agama memiliki peran penting di masyarakat untuk saling mengasihi satu sama lain sehingga tercipta keamanan dan kenyamanan dalam hidup penuh keberagaman. (Mohammed, 2019) mengungkapkan bahwa religiusitas memiliki hubungan terhadap kriminalitas terlepas dari apapun agama yang dianut, agama akan mereduksi kemungkinan seseorang untuk berbuat kriminal dan kenakalan. Perasaan aman seseorang akan tercipta apabila dalam suatu daerah minim kriminalitas dan ancaman. Keamanan menjadi aspek penting dalam hidup bersama masyarakat yang beragam di Indonesia.

Menurut Badan Pusat Statistika (2018) terdapat 336,652 kasus kriminal pada tahun 2017 di Indonesia, angka tersebut masih cukup tinggi meskipun sudah turun sebesar $5.75 \%$ dibandingkan tahun sebelumnya. Risiko terkena tindak kejahatan pada tahun 2017 mencapai 129 jiwa per 100,000 penduduk. Akan tetapi, masih banyak tindak kriminal yang oleh masyarakat tidak dilaporkan ke polisi. Data dari Markas Besar Kepolisian Republik Indonesia (Mabes Polri) menunjukkan bahwa Sumatera Utara menjadi provinsi yang memiliki pelaporan terjadinya tingkat kejahatan paling tinggi sebesar 39,867 kasus. Sedangkan Maluku Utara menjadi provinsi dengan pelaporan tindak kejahatan terendah dengan 'hanya' 789 kasus yang dilaporkan ke Kepolisian Daerah. Adapun tingkat risiko terkena tindak kriminal tertinggi terdapat pada provinsi Sulawesi Tengah dengan perbandingan 345 jiwa per 100,000 penduduk. Sedangkan tingkat risiko terkena tindak kriminal terendah berada pada provinsi Jawa Tengah dengan rasio 35 jiwa per 100,000 penduduk.

Indonesia dikenal sebagai negara yang memberikan perhatian khusus terhadap agama dan sangat menjunjung kerukunan umat beragama, sehingga Indonesia dikenal sebagai negara yang cukup religius. Akan tetapi perkembangan ajaran agama di Indonesia belum merata, masih terpusat di Pulau Jawa saja. Adanya ajaran agama yang kuat di Pulau Jawa dapat menjadi salah satu alasan bahwa Jawa menjadi provinsi dengan tingkat risiko terkena tindak kejahatan yang rendah dengan kasus kejahatan terlapor yang sedikit. Tetapi, kondisi keamanan di sebuah daerah tidak ditentukan hanya oleh faktor ajaran agama saja. Namun, bagaimana masyarakat dapat mengimplementasikan ajaran tersebut dan menjadi individu yang religius dan berdampak positif pada lingkungannya sehingga tercipta keamanan sosial. Oleh sebab itu, penelitian ini memiliki 2 (dua) tujuan sebagaimana berikut: Pertama, menganalisis pengaruh religiusitas dan kegiatan spiritual terhadap persepsi keamanan penganut agama-agama di Indonesia. Kedua, menganalisis persepsi keamanan berdasarkan keadaan setiap agama sebagai mayoritas dan minoritas di Indonesia

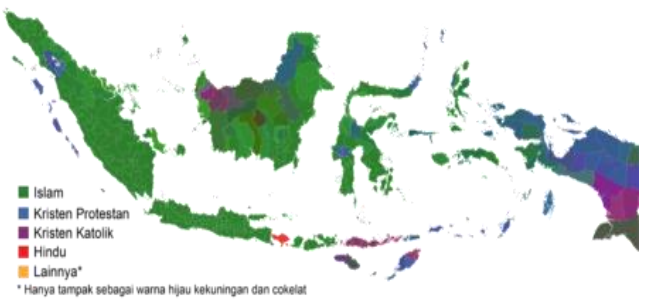

Gambar 1. Persebaran Agama-agama di Indonesia

Secara teori, jika ajaran agama diamalkan dengan baik maka akan menuntun individu menjadi seorang yang religius (Cohen \& Hill, 2007). Apabila religiusitas tersebut dipelihara dengan baik dengan melakukan kegiatan spiritual secara rutin dalam waktu tertentu maka akan menciptakan individu dengan perilaku yang baik dalam kehidupan bermasyarakat. Perilaku yang baik meliputi perbuatan pada dirinya sendiri dan orangorang disekitarnya. Selain itu, religiusitas yang diiringi pemeliharan kondisi rohani akan menimbulkan kebahagian, ketenangan dalam diri dan persepsi keamanan yang baik pada lingkungan individu tersebut (Stavrova, Fetchenhauer, \& Schlösser, 2013). Teori tersebut akan dibuktikan dalam penelitian ini dengan melihat faktor religiusitas dan kegiatan spiritual masing-masing agama terhadap persepsi keamanan di Indonesia.

\section{Tinjauan Pustaka}

Mayoritas dari penelitian sebelumnya dilakukan dengan pendekatan religiusitas terhadap tingkat kriminalitas. Seperti penelitian yang dilakukan oleh (Ellis, 1985), (Ellis \& Peterson, 1996) (Knudten \& Knudten, 1971) (Evans, Cullen, Dunaway, \& Burton, 1995) dan (Johnson, Jang, Larson, \& De Li, 2001) tentang relevansi religiusitas dengan etiologi tindak kriminalitas. Hasil 
penelitiannya menunjukkan bahwa terdapat hubungan kausalitas dua arah antara religiusitas dan tingkat kejahatan. Namun penelitian (Warr, 2017) mencoba melihat sudut pandang lain dari kemungkinan terjadinya kriminalitas yakni memperhatikan siklus kehidupan pernikahan seseorang. Seseorang yang telah menikah akan merasa lebih aman dan menurunkan tingkat risiko terjadinya kriminalitas terhadap seseorang tersebut.

(Stansfield, Mowen, O'Connor, \& Boman, 2017) juga melakukan penelitian mengenai hubungan agama dan kriminalitas, Stansfield mengungkapkan bahwa sudah banyak hasil penelitian mengenai peran agama dalam pengurangan angka kejahatan, namun penelitian yang ada belum memberikan kesimpulan yang berarti. Dalam penelitiannya ditemukan bahwa dukungan religiusitas memberikan dampak positif pada kondisi prososial dan mampu mengurangi tindak kejahatan. Akan tetapi religiusitas menjadi tidak signifikan secara statistik apabila variabel dukungan sosial ditambahkan ke dalam model penelitian. Dapat disimpulkan bahwa dukungan sosial dari masyarakat sekitar juga berarti terhadap keamanan di lingkungan individu. Selain itu menurut penelitian Lim dinyatakan bahwa dukungan sosial, religiusitas dan spiritualitas secara bersama-sama akan memberikan energi positif dan ketenangan dalam diri. Hal tersebut dibuktikan melalui percobaan pada pasien yang terpapar penyakit kanker di Korea (J. W. Lim \& Yi, 2009).

Sebuah penelitian juga dilakukan oleh Souryal mengenai hubungan religiusitas Islam dan kriminalitas di Arab Saudi yang merupakan negara dengan mayoritas penduduk Muslim dan menggunakan hukum Islam. Souryal menemukan bahwa dengan penerapan hukum syariat dan religiusitas Islam masyarakat Arab Saudi, jarang ditemukan tindak kriminal di daerah tersebut. Bahkan Arab Saudi memiliki tingkat kejahatan yang sangat rendah dibandingkan negara-negara Muslim lainnya. Selain faktor religiusitas, hukum syariat yang digunakan juga mempengaruhi rendahnya kriminalitas. Souryal juga mengkritisi kebijakan negara Barat yang tinggi kriminalitasnya karena mengabaikan norma agama dan memilih menggunakan hukum positif yang merupakan produk pikir manusia (Souryal, 1987).
Di Indonesia sendiri, (Utaberta, 2014) melakukan penelitian terhadap interaksi sosial dan kriminalitas di wilayah perumahan. Hasil menunjukkan bahwa budaya kekerabatan penghuni, dimana hubungan antar penghuni perumahan yang erat akan membuat setiap orang dalam lingkungan saling peduli satu sama lain dan mendukung tingkat keamanan lingkungan. Masyarakat yang religius cenderung lebih puas terhadap kehidupannya karena sering mengikuti aktivitas keagamaan dan mampu membangun jejaring sosial dengan baik (C. Lim \& Putnam, 2010). Penelitian Malhotra menunjukkan bahwa ajaran dan norma dalam agama juga terbukti dapat menciptakan perilaku yang baik antar sesama (Malhotra, 2010).

Penelitian Aziz tentang Transformasi Perilaku Masyarakat Beragama di Kabupaten Batanghari Jambi juga mengungkapkan bahwa keamanan dan kondisi sosial menjadi bagian penting dalam kebutuhan manusia, religiusitas berperan dalam mewujudkan kebutuhan ini. Namun terjadi transformasi nilai religiusitas sebagai akibat dari krisis identitas, rasa bangga melanggar aturan dan kontrol pemerintah yang lemah, pendangkalan nilai religiusitas berdampak negatif pada pelemahan psikis, intelektualitas dan jasmani masyarakat (Abd. Aziz, 2018).

Meskipun religiusitas dan aktivitas spiritual dapat memberikan kepuasan hidup dan menciptakan perilaku individu yang baik, hal tersebut tidak menjamin keamanan khususnya pada minoritas. Seperti penelitian yang dilakukan oleh MacDougall terhadap masyarakat Budha di Lombok-Indonesia sebagai minoritas. Masyarakat Budha sering diprimitifkan oleh Muslim Sasak yang dominan. Selama dipimpin oleh Muslim, Lombok dipercepat dengan mobilisasi milisi Muslim semi-terorganisir selama kerusuhan anti-Kristen tahun 2000. Masyarakat Budha juga mendapatkan serangan dan ancaman dari kelompok milisi tersebut (MacDougall, 2005).

Rasa aman tidak hanya ditentukan oleh rendahnya tingkat kriminalitas, namun rasa aman secara komprehensif dimana seorang individu dapat merasakan kebahagiaan subjektif di lingkungan individu tersebut tinggal. Artinya individu tersebut memiliki lingkungan sosial yang mengayomi satu sama lain, meskipun dalam lingkungan tersebut terdapat keragaman latar belakang agama dan 
budaya. Hasil studi (Pabbajah, Abdullah, Juhansar, \& Jubba, 2019) menunjukkan bahwa di Indonesia sendiri terdapat berbagai pergerakan keagamaan yang sangat beragam.

Momtaz mengungkapkan bahwa isolasi sosial memberikan pengaruh negatif terhadap keamanan psikologis seseorang. Dalam penelitiannya ditemukan bahwa religiusitas ternyata memiliki peran signifikan dalam memoderasi hubungan antara isolasi sosial dan keamanan psikologis, Momtaz menggunakan variabel usia, jenis kelamin, status pernikahan, tingkat pendidikan, pekerjaan, pendapatan dan lokasi tempat tinggal (Momtaz, Hamid, Ibrahim, Yahaya, \& Chai, 2011).

Penelitian yang mendukung hipotesis penelitian ini dilakukan juga oleh (Vail, Arndt, \& Abdollahi, 2012) tentang pengaruh aktivitas spiritual terhadap religiusitas pada agama Kristen, Islam, Atheis dan Agnostik. Vail menemukan bahwa perenungan spiritual terhadap kematian akan meningkatkan religiusitas pada agama Kristen dan Islam namun tidak pada masyarakat Atheis dan Agnostik. Kegiatan spiritual memberikan pengaruh positif terhadap religiusitas, religiusitas memiliki dampak perilaku sosial yang baik dan dampak perilaku sosial yang baik akan meningkatkan keamanan sosial dalam sebuah masyarakat dengan berbagai latar belakang agama karena adanya rasa saling percaya satu sama lain.

Keterkaitan antara peran agama dan keamanan juga dapat dijelaskan melalui intervensi politik dan tujuan keagamaan dalam menjaga keamanan bersama, beberapa penelitian yang membuktikan hubungan antara agama dan keamanan komprehensif juga dilakukan oleh (Gearon, 2013), (Karyotis \& Patrikios, 2010), (Toft, 2007) dan (Kinnvall, 2004). Beberapa penelitian sebelumnya yang menggunakan data IFLS untuk variabel pengaruh agama dan budaya antara lain dilakukan oleh (Widyaningrum \& Yu, 2018) dan (Gaduh, 2012).

Sehingga hal unik yang terdapat dalam penelitian ini adalah melakukan penelitian terhadap religiusitas dan aktivitas spiritual terhadap perspektif yang lain yakni persepsi keamanan individu. Perspektif tersebut guna melengkapi penelitian sebelumnya yang lebih menekankan tingkat keamanan pada angka terjadinya kriminalitas.

\section{Metodologi Penelitian}

Penelitian ini menggunakan data sekunder yang diperoleh melalui Indonesian Family Life Surveys Wave 5 (IFLS-5) yang disediakan secara terbuka oleh Lembaga Penelitian RAND dan Survey Meter (Strauss, Witoelar, \& Sikoki, 2016). Data IFLS merupakan data survei longitudinal yang mencakup keadaan sosial budaya, ekonomi dan kesehatan yang dilakukan terhadap individu dan rumah tangga di 13 dari 27 provinsi dengan penduduk terbanyak di Indonesia. Data ini dapat merepresentasikan $83 \%$ kondisi total populasi yang dipublikasikan tersedia dalam website RAND (rand.org).

Pada penelitian ini, digunakan data pada Buku 3A bagian TR (Trust) yang memuat data tentang tingkat persepsi keamanan (security level) seseorang di sebuah daerah baik siang ataupun malam hari, religiusitas individu, aktivitas keagamaan individu dan data-data pribadi lainnya seperti jenis kelamin, usia, agama, status pernikahan dan afilisasi organisasi keagamaan dengan detail deskripsi panduan pengguna dapat dilihat pada (Strauss dkk., 2016). IFLS Gelombang ke-5 merupakan data survei pada tahun 2014 hingga 2015.

Penelitian ini menggunakan analisis deskriptif sebagai pendekatan kualitatif dan analisis regresi linear berganda sebagai pendekatan kuantitatif. Pendekatan kuantitatif tersebut dilakukan untuk mengetahui bagaimana pengaruh faktor-faktor terkait terhadap variabel dependen yang diteliti (Abdullah \& Susamto, 2019), (Abdullah, 2018). Sedangkan pendekatan kualitatif dilakukan untuk membahas mengenai kondisi keagamaan dari sampel yang ada. Pertanyaan dalam survei IFLS yang diajukan oleh RAND untuk mengetahui tingkat persepsi keamanan seorang individu adalah sebagai berikut:

Q1. "Seberapa aman desa/kelurahan ini menurut Ibu/Bapak/Saudara (I/B/S)?"

Q2. "Di sebagian besar wilayah desa/kelurahan ini, apakah aman bagi $I / B / S$ untuk berjalan seorang diri di malam hari?"

Tingkat persepsi keamanan yang dimaksud adalah rasa aman secara fisik dan psikologis. Aman secara fisik artinya bebas dari sesuatu yang mengancam jiwa atau harta benda seseorang. Aman secara psikologis artinya memiliki lingkungan tempat tinggal 
yang bersih, sehat dan tetangga yang baik dan dapat dipercaya meskipun berbeda agama. Tingkat persepsi keamanan menjadi variabel dependen yang ingin diteliti dalam penelitian ini, digunakan dua variabel untuk menguji robustness sekaligus mengetahui perbedaan dampak kondisi religiusitas dan aktivitas keagamaan individu terhadap persepsi rasa aman di siang dan malam hari. Sedangkan variabel independen yang ingin diteliti terlihat pada tabel 1, tentang pertanyaan faktor kegiatan spiritual agama di Indonesia.

Tabel 1. Pertanyaan Faktor Kegiatan Spiritual Agama di Indonesia

\begin{tabular}{|c|c|c|}
\hline No & Variabel & Pertanyaan \\
\hline 1 & Religiusitas & $\begin{array}{l}\text { Menurut } \\
\text { Ibu/Bapak/Saudara, } \\
\text { seberapa taatkah } \\
\text { I/B/S dalam } \\
\text { beragama? }\end{array}$ \\
\hline \multirow[t]{2}{*}{2} & \multirow{2}{*}{$\begin{array}{l}\text { Aktivitas } \\
\text { Keagamaan } \\
\text { Islam }\end{array}$} & $\begin{array}{l}\text { Berapa kali I/B/S } \\
\text { shalat dalam sehari? }\end{array}$ \\
\hline & & $\begin{array}{l}\text { Apakah I/B/S pernah } \\
\text { mendatangi majelis } \\
\text { ta'lim/ceramah } \\
\text { keagamaan } \\
\text { /pengajian dalam } 12 \\
\text { bulan terakhir? } \\
\text { Berapa kali? }\end{array}$ \\
\hline \multirow[t]{2}{*}{3} & \multirow{2}{*}{$\begin{array}{l}\text { Aktivitas } \\
\text { Keagamaan } \\
\text { Katolik \& } \\
\text { Protestan }\end{array}$} & $\begin{array}{l}\text { Berapa kali I/B/S } \\
\text { berdoa dalam sehari? }\end{array}$ \\
\hline & & $\begin{array}{l}\text { Apakah I/B/S aktif } \\
\text { berpartisipasi dalam } \\
\text { kegiatan keagamaan } \\
\text { seperti persekutuan } \\
\text { doa dan lainnya } \\
\text { dalam } 12 \text { bulan } \\
\text { terakhir? Berapa } \\
\text { kali? }\end{array}$ \\
\hline \multirow[t]{2}{*}{4} & \multirow[t]{2}{*}{$\begin{array}{l}\text { Aktivitas } \\
\text { Keagamaan } \\
\text { Hindu }\end{array}$} & $\begin{array}{l}\text { Apakah I/B/S } \\
\text { melakukan risadya/ } \\
\text { meditasi/ yoga/ } \\
\text { sembahyang ke } \\
\text { pura/sanggah/meraja } \\
\text { n/candi? Berapa kali? }\end{array}$ \\
\hline & & $\begin{array}{l}\text { Apakah I/B/S } \\
\text { melakukan } \\
\text { pantangan makan } \\
\text { tertentu karena alasan } \\
\text { keagamaan untuk } \\
\text { perkembangan } \\
\text { spiritual? }\end{array}$ \\
\hline 5 & & $\begin{array}{l}\text { Apakah I/B/S } \\
\text { melakukan puja }\end{array}$ \\
\hline
\end{tabular}

\begin{tabular}{l|l|}
$\begin{array}{l}\text { Aktivitas } \\
\text { Keagamaan }\end{array}$ & mantra/ meditasi/ ke \\
Budha & Vihara/ doa di \\
& rumah? Berapa kali? \\
& $\begin{array}{l}\text { Apakah I/B/S } \\
\text { vegetarian } \\
\text { sebagaimana ajaran } \\
\text { Budha? }\end{array}$
\end{tabular}

Sumber : IFLS Gelombang ke-5 (RAND, 2015)

Tidak dilakukan perubahan data apapun terhadap tingkat keamanan sebagai variabel dependen oleh penulis, akan tetapi dilakukan penyesuaian data skala terhadap varibael independen seperti penyesuaian ketersediaan data dan skala yang digunakan agar tidak terjadi bias dalam analisis regresi. Skala yang digunakan yakni 1-4 untuk religiusitas dan aktivitas keagamaan, dimana angka 1 menunjukkan sangat religius dan rajin dalam mengikuti aktivitas keagamaan. Semakin mendekati angka 4 maka seseorang semakin mengakui bahwa dirinya kurang religius dan jarang mengikuti aktivitas keagamaan. Khusus untuk Agama Budha, digunakan variabel dummy untuk mengukur religiusitas dan aktivitas keagamaan sebagai penyesuaian terhadap kondisi data. Model analisis regresi yang dilakukan dalam penelitian ini adalah sebagai berikut:

$$
\begin{aligned}
Y_{i}=\beta_{0}+\beta_{1} \text { Relig }+\beta_{2} A c t 1+\beta_{3} A c t 2 \\
+\beta_{4} X_{4}+\beta_{5} X_{5}+\beta_{6} X_{6}+e_{i}
\end{aligned}
$$

Dimana,

$$
\begin{aligned}
Y i= & \begin{array}{l}
\text { Tingkat keamanan individu di } \\
\text { daerah secara umum \& malam }
\end{array} \\
\text { hari } & \\
\text { Relig }= & \begin{array}{l}
\text { Religiusitas (Ketaatan dalam } \\
\text { beragama }
\end{array} \\
& \begin{array}{l}
\text { Islam/Katolik/Protestan/Hindu/ } \\
\text { Budha) }
\end{array} \\
\text { Act1 }= & \text { Aktivitas keagamaan-1 (ibadah } \\
& \text { individu } \\
& \text { Islam/Katolik/Protestan/Hindu/ } \\
& \text { Budha) } \\
& \text { Aktivitas keagamaan-2 (ibadah } \\
& \text { individu } \\
\text { Act2 } & \text { Islam/Katolik/Protestan/Hindu/ } \\
& \text { Budha) } \\
= & \text { Variabel kontrol } \\
= & \text { Galat } / \text { Error }
\end{aligned}
$$

Analisis regresi dilakukan secara terpisah kepada setiap agama yakni agama Islam, Katolik, Protestan, Hindu dan Budha sebagai agama yang diakui di Indonesia. Sedangkan analisis regresi tidak dilakukan pada agama 
Konghucu karena ketersediaan data yang terbatas. Selain itu, variabel kontrol yang digunakan adalah jenis kelamin (gender), status pernikahan (marital status) dan usia (age) sebagai faktor yang memungkinkan untuk memberikan pengaruh kepada tingkat persepsi keamanan individu namun tidak menjadi fokus pembahasan.

\section{Hasil dan Diskusi}

\section{Analisis Deskriptif Data}

Setelah melalui pengolahan data, maka didapatkan total sampel sebanyak 32,466 individu yang terdiri dari 29,208 individu beragama Islam (89.96\%), 417 individu beragama Katolik (1.28\%), 1.258 individu beragama Protestan (3.87\%), 1,537 individu beragama Hindu (4.73\%) dan 46 orang beragama Budha $(0.14 \%)$. Pada tabel 2, terlihat bahwa perbandingan agama dan religiusitas masing-masing responden.

Tabel 2. Perbandingan Agama dan Religiusitas pada Responden

Seberapa Taatkah Ibu/Bapak/Saudara dalam

\begin{tabular}{lllllll} 
& & \multicolumn{6}{c}{$\begin{array}{l}\text { Seberapa Taatkah } \\
\text { No }\end{array}$} & Agama & \multicolumn{2}{c}{\begin{tabular}{l} 
Beragama? \\
\cline { 3 - 7 }
\end{tabular}} & $\begin{array}{c}\text { Sangat } \\
\text { Taat }\end{array}$ & Taat & $\begin{array}{c}\text { Kurang } \\
\text { Taat }\end{array}$ & $\begin{array}{c}\text { Tidak } \\
\text { Taat }\end{array}$ & Total \\
\hline 1. & Islam & 4,374 & $\begin{array}{l}17,7 \\
19\end{array}$ & 6,286 & 829 & $\begin{array}{l}29,20 \\
8\end{array}$ \\
\hline 2. & $\begin{array}{l}\text { Katholi } \\
\text { k }\end{array}$ & 72 & 254 & 85 & 6 & 417 \\
\hline 3. & $\begin{array}{l}\text { Protest } \\
\text { ant }\end{array}$ & 224 & 817 & 186 & 31 & 1,258 \\
\hline 4. & Hindu & 622 & 822 & 87 & 6 & 1,537 \\
\hline 5. & Budha & 2 & 32 & 10 & 2 & 46 \\
\hline & Total & 5,294 & 19,6 & 6,654 & 874 & $\begin{array}{l}32,46 \\
6\end{array}$ \\
\hline
\end{tabular}

Sumber : Data diolah (2019)

Berdasarkan Tabel 2 di atas, dapat terlihat bahwa religiusitas seseorang dalam beragama hampir mirip antara satu agama dengan yang lainnya, dimana setiap penganut agama mendominasi level "Taat" dalam beragama, kemudian "Kurang Taat" untuk agama Islam, Katholik dan Budha dan "Sangat Taat" untuk agama Protestan dan Hindu. Sedangkan mayoritas dari responden sedikit yang menjawab "Tidak Taat". Berdasarkan karakteristik responden yang ada, maka dapat disimpulkan bahwa responden memiliki ratarata level religiusitas menengah ke atas, hal ini sesuai dengan persepsi publik bahwa Indonesia adalah negara yang religius dan dekat dengan nilai-nilai agama.

Kondisi ketaatan individu dalam beragama di sebuah daerah seharusnya dapat menciptakan iklim positif pada lingkungan di sekitarnya, hal tersebut dapat dicerminkan melalui rasa aman yang muncul pada individu-individu yang ada, baik rasa aman dari kejahatan atau tindak kriminal serta rasa aman dari tekanan psikologis lingkungan atau tetangga yang beragam. Secara teori, seseorang dengan religiusitas yang baik akan bersikap baik terhadap sesamanya, saling melindungi dan tidak menyakiti satu sama lain sehingga efek positif tersebut dapat menekan angka kriminalitas di sebuah daerah. Seorang dengan religiusitas yang baik juga akan lebih yakin bahwa Tuhan selalu bersamanya, menjaganya dan melindunginya dari segala bentuk kejahatan sehingga perasaan aman dan tenang selalu membersamainya. Hal tersebut dibuktikan dari analisis pada Tabel 3 berikut.

Tabel 3. Deskriptif Perbandingan Religiusitas \& Persepsi Keamanan di Indonesia

\begin{tabular}{|c|c|c|c|c|}
\hline $\begin{array}{c}\text { Tingkat } \\
\text { Religiusitas }\end{array}$ & $\begin{array}{l}\text { Sangat } \\
\text { Aman }\end{array}$ & Aman & $\begin{array}{l}\text { Tidak } \\
\text { Aman }\end{array}$ & $\begin{array}{l}\text { Sangat } \\
\text { Tidak } \\
\text { Aman }\end{array}$ \\
\hline Sangat Taat & 825 & 3,327 & 1,044 & 98 \\
\hline Taat & 1,296 & 14,438 & 3,699 & 211 \\
\hline Agak Taat & 525 & 4,571 & 1,448 & 110 \\
\hline Tidak Taat & 100 & 588 & 166 & 20 \\
\hline Total & 2,746 & 22,924 & 6,357 & 439 \\
\hline
\end{tabular}

Berdasarkan Tabel 3 di atas, maka dapat terlihat bahwa kondisi desa dan kelurahan yang diteliti relatif sudah aman. Mayoritas responden yang mengakui bahwa dirinya taat dalam beragama sudah merasakan keamanan dan sangat aman di daerahnya, hanya sebagian kecil yang merasakan kondisi tidak aman atau khawatir akan terjadi ancaman fisik atau psikologis terhadap dirinya dan hal tersebut berasal dari kalangan individu yang kurang religius. Oleh sebab itu, selanjutnya akan dilakukan analisis regresi untuk mengetahui secara umum pengaruh religiusitas dan kegiatan keagamaan individu terhadap keamanan tersebut. Analisis dilakukan dengan mengkategorikan individu berdasarkan agama yang dianut, hal tersebut berfungsi untuk mengetahui perbedaan tingkat keamanan yang dialami oleh mayoritas dan minoritas.

\section{Pengaruh Religiusitas dan Kegiatan Agama Islam terhadap Persepsi Keamanan}

Sebagai agama mayoritas di Indonesia dengan jumlah penganut sebanyak kurang lebih $87 \%$ dari populasi, maka responden beragama Islam yang diambil untuk mewakili 
populasi adalah yang terbanyak yakni 29,208 individu. Berdasarkan data dari IFLS-5, dari sampel tersebut $66.06 \%$ dekat dengan lingkungan tradisi Nahdlatul Ulama (NU), $11.88 \%$ dekat dengan tradisi Muhammadiyah, $18.05 \%$ tidak dekat dengan tradisi Islam apapun dan $4.01 \%$ dekat dengan tradisi organisasi masyarakat Islam yang lain. Secara umum, dalam tradisi apapun dalam Islam diajarkan untuk bersilaturrahmi kepada tetangga, berbuat baik dan saling tolong menolong antar sesama serta yakin dan percaya bahwa Tuhan selalu mengawasi dan menjaga hamba-Nya. Oleh sebab itu, seorang Islam yang baik akan semakin merasakan kedamaian dalam dirinya apapun yang terjadi, termasuk rasa aman dan percaya bahwa Tuhan akan menjaganya. Karena apabila dalam sebuah lingkungan religius, maka konflik yang terjadi akan sangat minim. Berikut adalah hasil analisis hubungan antara religiusitas, aktivitas pengajian atau taklim orang Islam terhadap tingkat keamanan dalam persepsi individu.

Tabel 4. Luaran Analisis Regresi Religiusitas dan Kegiatan Spiritual Agama Islam terhadap Persepsi Keamanan

\begin{tabular}{lcc} 
Variabel & $\begin{array}{c}\text { Aman di } \\
\text { Daerah }\end{array}$ & $\begin{array}{c}\text { Aman di } \\
\text { Malam Hari }\end{array}$ \\
\hline Religiusitas Islam & $0.1062^{* * *}$ & $0.0290^{* * *}$ \\
Sholat & $(0.005)$ & $(0.005)$ \\
& 0.0038 & -0.0020 \\
Pengajian/Taklim & $(0.003)$ & $(0.003)$ \\
& $0.0051^{* *}$ & 0.0035 \\
Jenis Kelamin & $(0.002)$ & $(0.002)$ \\
& $-0.0643 * * *$ & $-0.3196 * * *$ \\
Usia & $(0.006)$ & $(0.006)$ \\
& 0.0002 & $-0.0050 * * *$ \\
Status Pernikahan & $(0.000)$ & $(0.000)$ \\
& 0.0048 & 0.0018 \\
Constant & $(0.007)$ & $(0.007)$ \\
& $1.6288 * * *$ & $2.4109 * * *$ \\
Observations & $(0.016)$ & $(0.017)$ \\
R-squared & 29,208 & 29,208 \\
Keterangan : Standard errors in parentheses, $* * *$ \\
p<0.01, ** p $<0.05, * \mathrm{p}<0.1$ & \\
Sumber : Data diolah $(2019)$ &
\end{tabular}

Hasil analisis regresi pada tabel 4, menunjukkan bahwa religiusitas penganut agama Islam di Indonesia berpengaruh positif dan signifikan pada taraf nyata statistik $1 \%$ terhadap persepsi keamanan. Hal tersebut sangatlah wajar karena sudah menjadi budaya di Indonesia apabila terdapat tokoh yang dianggap religius maka akan dilindungi dan dihormati sedapat mungkin seperti Ulama', Kyai, Ustadz ataupun Habib. Religiusitas juga menuntun orang Islam terhadap ketenangan hidup dan keyakinan bahwa Tuhan selalu akan menolongnya dalam kondisi apapun. Tingkat religiusitas agama Islam dalam responden didominasi oleh jawaban "Taat". Sehingga dapat disimpulkan bahwa orang Islam di Indonesia masih terus berusaha untuk memperbaiki dirinya agar menjadi "Sangat Taat". Orang Islam akan meningkatkan spiritualitasnya melalui kegiatan ritual seperti sholat dan pengajian atau taklim.

Berdasarkan hasil analisis di atas, sholat dan intensitas mengikuti pengajian juga memberikan pengaruh positif yang signifikan terhadap persepsi keamanan seorang Muslim. Muslim dianjurkan untuk melakukan sholat secara berjama'ah di Masjid. Masjid di Indonesia sangat banyak jumlahnya, sehingga kegiatan sholat yang dilakukan oleh orang Islam akan menuntun kepada interaksi sosial terhadap sesamanya selama di Masjid. Akan tetapi sholat memiliki pengaruh negatif di malam hari, hal tersebut dapat disebabkan karena orang merasa tidak aman apabila bepergian sholat di masjid pada sholat Isya' dan Shubuh. Sebagaimana kondisi sosial yang terjadi di Indonesia seringkali kriminalitas terjadi saat shubuh hari.

Pada variabel intensitas mengikuti pengajian, semakin sering seorang Muslim mengikuti pengajian maka dirinya akan merasa semakin aman karena di dalam pengajian akan terjalin silaturrahmi satu sama lain antar jama'ah sehingga meningkatkan keakraban bertetangga dan beragama. Dengan adanya interaksi sosial sebagai akibat dari kegiatan spiritual tersebut, maka akan meningkatkan persepsi keamanan seseorang.

Hal yang menjadi temuan unik adalah meskipun hanya menjadi variabel kontrol, ternyata jenis kelamin memberikan pengaruh yang signifikan pada taraf nyata $1 \%$ dan negatif. Artinya seorang laki-laki memiliki persepsi keamanan yang rendah dibandingkan seorang wanita. Padahal, kondisi yang wajar dalam Islam adalah seorang laki-laki merasa lebih aman daripada wanita karena laki-laki merupakan pelindung wanita. Namun hal tersebut tidak berlaku pada analisis ini, hal 
tersebut dapat disebabkan karena wanita dalam Islam dianjurkan untuk tidak terlalu sering keluar rumah, khususnya pada malam hari untuk menjaga martabat dan kehormatan wanita tersebut. Faktor konstanta juga signifikan dalam luaran regresi ini, artinya persepsi keamanan juga dapat dipengaruhi oleh variabel lain di luar model seperti daerah provinsi tempat tinggal, pekerjaan yang dimiliki, tingkat pendidikan, dukungan sosial dan lain sebagainya. Hal ini sesuai dengan penelitian yang dilakukan oleh (Momtaz dkk., 2011).

\section{Pengaruh Religiusitas dan Kegiatan Agama Katolik \& Protestan terhadap Persepsi Keamanan}

Katolik dan Protestan merupakan agama mayoritas kedua di Indonesia dengan jumlah penganut sebesar $7 \%$ dari populasi, meskipun jumlah penganutnya jauh dibandingkan dengan penganut agama Islam. Namun, jumlah gereja di Indonesia saat ini tumbuh cukup drastis dari tahun ke tahun. Agama ini didominasi oleh penduduk Indonesia wilayah Timur. Dari hasil pengolahan data, terdapat 1,675 responden beragama Katolik dan Protestan dalam penelitian ini. Berdasarkan hasil analisis deskriptif maka ditemukan bahwa lebih $75 \%$ responden merasa taat dalam beragama. Dari $75 \%$ tersebut, hampir $90 \%$ merasa aman untuk hidup di lingkungan tempat tinggalnya.

Tabel 5. Luaran Analisis Regresi Religiusitas dan Kegiatan Spiritual Agama Katolik \& Protestan terhadap Persepsi Keamanan

\begin{tabular}{lcc} 
Variabel & $\begin{array}{c}\text { Aman di } \\
\text { Daerah }\end{array}$ & $\begin{array}{l}\text { Aman di } \\
\text { Malam } \\
\text { Hari }\end{array}$ \\
\hline Religiusitas & & \\
Katolik \& & & \\
Protestan & $0.1100 * * *$ & $0.0344 *$ \\
& $(0.020)$ & $(0.021)$ \\
Ibadah Berdoa & 0.0109 & 0.0034 \\
Individu & $(0.011)$ & $(0.012)$ \\
& & \\
Persekutuan Doa & -0.0195 & -0.0053 \\
Gereja & $(0.013)$ & $(0.013)$ \\
& $-0.0547 * *$ & $-0.3177 * * *$ \\
Jenis Kelamin & $(0.025)$ & $(0.026)$ \\
& $-0.0016 * *$ & $-0.0047 * * *$ \\
Usia & $(0.001)$ & $(0.001)$ \\
& 0.0114 & -0.0284 \\
Status Pernikahan & $(0.027)$ & $(0.028)$ \\
& $1.7633^{* * *}$ & $2.3724 * * *$ \\
Constant & $(0.060)$ & $(0.063)$ \\
& 1,675 & 1,675 \\
Observations & 0.027 & 0.103 \\
R-squared & & \\
\hline
\end{tabular}

Keterangan: Standard errors in parentheses, *** $\mathrm{p}<0.01, * * \mathrm{p}<0.05, * \mathrm{p}<0.1$

Sumber : Data diolah (2019)

Secara umum memang religiusitas memiliki pengaruh positif dan signifikan terhadap persepsi keamanan orang Katolik dan Protestan. Hal tersebut karena orang yang religius akan cenderung berbuat baik terhadap sesama, dan lingkungan sekitarnya pun juga akan berbuat baik sedemikian rupa sehingga tercipta ekosistem yang aman dalam tempat tinggalnya tanpa melihat latar belakang agama dari tetangga di sekitarnya.

Terlihat pada tabel 5, hasil luaran analisis regresi menunjukkan, kegiatan spiritual orang Katolik dan Protestan berupa berdoa secara individu masih memiliki pengaruh positif terhadap persepsi keamanan. Akan tetapi kegiatan persekutuan doa bersama di gereja memberikan pengaruh negatif terhadap persepsi keamanan orang Katolik dan Protestan, baik saat siang ataupun malam hari di daerah tempat tinggalnya. Hal ini sejalan dengan kerap kali terjadinya fenomena pengeboman gereja yang dilakukan oleh orang-orang ekstrimis; lihat (Tabrani, 2019), (Misbah, Yusuf, \& Wijaya, 2019), (Widiani \& Jiyanto, 2018), (Kristianto, 2018) dan (Monitor, 2002). Fenomena pengeboman gereja yang terjadi beberapa kali tersebut ternyata membuat orang Katolik dan Protestan merasa khawatir untuk melakukan ibadah spiritual yakni persekutuan doa bersama di gereja. Sehingga meskipun dalam bermasyarakat di tempat tinggal orang Katolik dan Protestan sudah merasa aman, namun mereka tidak merasa aman di rumah ibadah mereka.

Maka wajar saja apabila saat pelaksanaan ibadah persekutuan doa bersama di gereja saat Malam Hari Minggu atau Hari Minggu dilakukan pengawasan ketat oleh pihak keamanan seperti polisi dan satuan pamong praja. Pengawalan tersebut adalah bukti bahwa masih terdapat kekhawatiran orang Katolik dan Protestan saat melakukan persekutuan doa di gereja, kekhawatiran tersebut muncul karena terancamnya keamanan dan keselamatan jiwanya saat melakukan sesi ibadah sebagai akibat dari fenomena pengeboman atau pendiskriminasian gereja oleh kaum ekstrimis. Perbedaan tersebut sangat jelas apabila dibandingkan oleh orang Islam yang dapat beribadah lima kali dalam sehari di 
masjid tanpa pengawalan sedikitpun di Indonesia.

Oleh sebab itu, penting bagi pemerintah dan masyarakat secara umum untuk terus meningkatkan persaudaraan dan kerukunan antar umat beragama di Indonesia. Hal tersebut bertujuan untuk menciptakan rasa aman dan saling percaya satu sama lain, khususnya bagi kaum-kaum agama minoritas. Menjadi individu yang religius bagi diri sendiri saja tidak cukup untuk menciptakan kerukunan, namun juga perlu untuk dapat menghargai prosesi peribadatan agama lain serta diberikan dukungan sosial yang dapat disampaikan melalui kegiatan pendidikan formal maupun literasi masyarakat.

\section{Pengaruh Religiusitas dan Kegiatan Agama Hindu terhadap Persepsi Keamanan}

Jumlah penganut agama Hindu di Indonesia berada di belakang Katolik dan Protestan dengan jumlah kurang lebih 1,7\% dari total populasi. Salah satu daerah yang terkenal dengan dominasi umat beragama Hindu adalah di Pulau Bali. Meskipun di Bali umat Hindu menjadi mayoritas, namun di Pulau Jawa, Sumatera, Kalimantan dan daerah lain Hindu merupakan minoritas. Terdapat total 1,537 responden beragama Hindu dalam penelitian ini dengan komposisi 93\% penganut agama Hindu merasa dirinya taat dalam beragama. Angka pengakuan religiusitas agama Hindu ini unik karena paling tinggi di antara agama yang lainnya. Dari $93 \%$ responden yang religius tersebut, hampir $95 \%$ nya merasakan keamanan di lingkungan tempat tinggalnya.

Agama Hindu memiliki kontribusi penting dalam sejarah perkembangan Bangsa Indonesia dengan adanya Kerajaan-kerajaan Hindu seperti Kerajaan Kutai, Tarumanegara, Kalingga dan yang paling menonjol adalah Kerajaan Mataram dan Majapahit yang memberikan pengaruh hampir ke seluruh Nusantara dengan Patih Gajah Mada sebagai salah satu tokoh pembesarnya. Pengaruh Kerajaan Hindu sangat kuat dalam menarik orang-orang Indonesia modern kepada agama Hindu hingga bergeser ke Bali pada abad ke16 setelah dihancurkan oleh negara-negara Islam di wilayah Jawa.

Tabel 6. Luaran Analisis Regresi Religiusitas dan Kegiatan Spiritual Agama Hindu terhadap Persepsi Keamanan

\begin{tabular}{lcc} 
Variabel & $\begin{array}{c}\text { Aman di } \\
\text { Daerah }\end{array}$ & $\begin{array}{c}\text { Aman di } \\
\text { Malam } \\
\text { Hari }\end{array}$ \\
\hline Religiusitas Hindu & $\begin{array}{c}0.2283 * * * \\
(0.022)\end{array}$ & $\begin{array}{c}0.0500 * * \\
(0.025)\end{array}$ \\
Meditasi/Sembahyang & 0.0184 & 0.0165 \\
ke Pura & $(0.014)$ & $(0.016)$ \\
& 0.0068 & -0.0056 \\
Diet Spiritual & $(0.030)$ & $(0.033)$ \\
& $-0.1407 * * *$ & $-0.3297 * * *$ \\
Jenis Kelamin & $(0.027)$ & $(0.030)$ \\
& $0.0024 * *$ & $-0.0053 * * *$ \\
Usia & $(0.001)$ & $(0.001)$ \\
& $-0.0595 *$ & -0.0403 \\
Status Pernikahan & $(0.032)$ & $(0.035)$ \\
& $1.2501 * * *$ & $2.3158 * * *$ \\
Constant & $(0.061)$ & $(0.068)$ \\
& 1,537 & 1,537 \\
Observations & 0.084 & 0.101 \\
R-squared & & \\
\hline Keterangan: Standard errors in parentheses, $* * *$ \\
p $<0.01, * * \mathrm{p}<0.05, * \mathrm{p}<0.1$
\end{tabular}

Hasil dari analisis regresi pada Tabel 6 di atas memperkuat bukti bahwa terdapat latar belakang pengaruh kewibawaan Agama Hindu hingga masa kini. Meskipun Hindu sudah dikalahkan oleh Negara Islam dan tidak mendominasi, namun para penganutnya masih merasa aman untuk tinggal di Indonesia. Meskipun hal tersebut bisa terjadi karena para penganut Agama Hindu berkumpul di Pulau Bali. Akan tetapi, hasil analisis menunjukkan bahwa secara umum, religiusitas Hindu dan kegiatan spiritualnya memiliki pengaruh positif dan signifikan terhadap persepsi keamanan para penganutnya pada daerahdaerah di Indonesia. Hasil ini sekaligus mengonfirmasi penelitian dari (Jubba, Pabbajah, Prasodjo, \& Qodir, 2019) yang menemukan bahwa umat Islam sebagai mayoritas dapat hidup rukun bersama umat Hindu sebagai minoritas di Sulawesi. Pura sebagai rumah ibadah umat Hindu pun cenderung lebih aman apabila dibandingkan dengan rumah ibadah Katolik dan Protestan yang memerlukan banyak penjagaan sebagaimana dipaparkan sebelumnya.

Terdapat sebuah ajaran Hindu bernama Ahimsa, yang merupakan tugas utama dari semua kasta di Hindu untuk melakukan gerakan anti-kekerasan terhadap semua bentuk kehidupan, baik pada manusia maupun 
hewan karena Hindu percaya untuk meminimalisir kematian hewan, hal serupa juga dijelaskan dalam (Valpey, 2018), (Skaria, 2015), (Ghassem-Fachandi, 2010) dan (Ghassem-Fachandi, 2006). Sehingga hal tersebut menuntun penganut agama Hindu menjadi seorang vegetarian yang selaras dengan alam dan menghormati bentuk kehidupan lain dengan tidak memakan daging tertentu. Dalam analisis regresi ini, diet spiritual agama Hindu berpengaruh positif terhadap persepsi keamanan individu di daerah secara umum namun berpengaruh negatif terhadap keamanan individu di malam hari meskipun tidak signifikan secara statistik. Hal tersebut berarti diet tidak dilakukan pada malam hari untuk menjaga stabilitas kondisi fisik dan psikis penganut agama Hindu. Namun secara umum, kegiatan spiritual memberikan pengaruh positif terhadap persepsi keamanan para penganut agama Hindu meskipun tidak signifikan secara statistik.

\section{Pengaruh Religiusitas dan Kegiatan Agama Budha terhadap Persepsi Keamanan}

Budha merupakan agama paling minoritas di Indonesia sebelum Konghucu diakui sebagai agama resmi dengan penganut sebanyak $0,7 \%$ dari total populasi di Indonesia. Sebagai minoritas tentu lebih banyak tantangan yang dihadapi oleh penganut agama ini. Penelitian ini menggunakan 46 responden yang beragama Budha. Meskipun minoritas, Budha juga memiliki kontribusi besar dalam sejarah penting dengan adanya Kerajaan HinduBudha yakni Sriwijaya dan Majapahit.

Terdapat beberapa kemiripan antara Hindu dan Budha yakni keduanya tumbuh dan berkembang di India dan selalu berusaha meletakkan dasar ajaran kebenaran ke dalam kehidupan manusia. Keduanya bertujuan untuk menyelamatkan umat manusia dari rasa kegelapan. Sehingga wajar apabila terdapat ajaran spiritual yang mirip antara keduanya seperti anjuran menjadi vegetarian dan tidak mengonsumsi daging bagi para penganutnya yang terdapat pada Lankavatara Sutra. Akan tetapi, ajaran untuk tidak mengonsumsi daging ini memang menjadi perdebatan di kalangan penganut Budha sendiri, yakni mengenai apakah mutlak semua daging tidak boleh dikonsumsi atau hanya daging tertentu saja. Namun secara umum, ajaran ini tidak sekuat sebagaimana ajaran vegetarian pada agama Hindu. Namun variabel ini digunakan sebagai salah satu kegiatan spiritual agama Budha, dapat dilihat pada tabel 7.

Tabel 7. Luaran Analisis Regresi Religiusitas dan Kegiatan Spiritual Agama Budha terhadap Persepsi Keamanan

\begin{tabular}{lcc} 
Variabel & $\begin{array}{c}\text { Aman di } \\
\text { Daerah }\end{array}$ & $\begin{array}{c}\text { Aman di } \\
\text { Malam Hari }\end{array}$ \\
\hline Religiusitas & & \\
Budha & -0.1579 & $-0.2701^{* *}$ \\
Puja Mantra ke & $(0.149)$ & $(0.129)$ \\
Vihara & $-0.7611^{* * *}$ & -0.3282 \\
Vegetarian & $(0.266)$ & $(0.230)$ \\
Budhism & $-0.4754 * *$ & -0.2974 \\
& $(0.220)$ & $(0.190)$ \\
Jenis Kelamin & -0.2023 & -0.0976 \\
& $(0.142)$ & $(0.123)$ \\
Usia & -0.0003 & $-0.0104 * *$ \\
& $(0.005)$ & $(0.004)$ \\
Status Pernikahan & -0.0265 & -0.0006 \\
& $(0.151)$ & $(0.131)$ \\
Constant & $3.3291 * * *$ & $3.5674 * * *$ \\
& $(0.563)$ & $(0.487)$ \\
Observations & 46 & 46 \\
R-squared & 0.301 & 0.293 \\
\hline Keter & &
\end{tabular}

Keterangan: Standard errors in parentheses, $* * *$ $\mathrm{p}<0.01, * * \mathrm{p}<0.05, * \mathrm{p}<0.1$

Sumber : Data diolah (2019)

Meskipun pernah berjaya pada sebuah kerajaan besar secara bersama-sama dengan agama Hindu, penganut agama Budha tidaklah sebanyak agama Hindu. Sangat sedikitnya penganut agama Budha di Indonesia dapat menjadi penyebab ketidakamanan jiwa dan psikis penganutnya. Berdasarkan hasil analisis regresi, faktor religiusitas dan kegiatan spiritual memberikan pengaruh negatif terhadap persepsi keamanan penganut agama Budha di Indonesia. Artinya, apabila seorang Budha berusaha menjadi seorang yang religius menurut ajarannya, maka perbuatan tersebut justru semakin membuatnya merasa tidak aman. Hal ini dapat disebabkan oleh adanya kemungkinan tekanan negatif dari lingkungan sekitar tempat tinggal seorang Budha seperti adanya ajakan untuk berpindah agama karena ajaran Budha dipandang tidak wajar dibandingkan dengan ajaran mayoritas.

Ibadah Puja Mantra ke Vihara juga berpengaruh negatif terhadap persepsi 
keamanan penganut agama Budha dan signifikan pada taraf nyata $1 \%$. Ini menjadi temuan yang dapat mengungkapkan bahwa keberadaan rumah ibadah agama Budha masih dianggap sebagai ancaman oleh mayoritas di Indonesia, sehingga ada tekanan tertentu yang menyebabkan seorang Budha merasa tidak aman ketika hendak melakukan ibadah ke Vihara. Aktivitas spiritual vegetarian sebagai ajaran agama Budha di Indonesia juga berpengaruh negatif dan signifikan pada taraf nyata $5 \%$. Berdasarkan data deskriptif, dari 46 responden Budha, hanya 6 orang yang melakukan ritual vegetarian dan 40 orang tidak melakukannya. Hal tersebut dapat mengonfirmasi bahwa terdapat perdebatan mengenai ajaran vegetarian di dalam agama Budha sendiri sehingga menimbulkan tekanan psikologis yang mengurangi persepsi keamanan seorang Budha. Secara umum dapat disimpulkan bahwa penganut Budha merasa keberadaannya sebagai minoritas kurang aman di Indonesia, baik secara fisik maupun psikologis.

\section{Kesimpulan}

Religiusitas dapat berperan untuk mereduksi tingkat kriminalitas karena setiap agama mengajarkan untuk berbuat baik terhadap sesama dan menciptakan iklim sosial yang baik. Religiusitas juga dapat ditingkatkan melalui pemeliharaan spiritual dengan melakukan peribadatan rutin yang diajarkan oleh masing-masing agama. Religiusitas tersebut juga akan menuntun seseorang untuk menemukan kedamaian, keamanan dan ketenangan dalam hidup. Seorang yang religius akan berdampak positif terhadap keamanan sosial lingkungan di sekitarnya. Secara teori, religiusitas dan kegiatan spiritual dapat mereduksi kriminalitas dan meningkatkan persepsi keamanan masyarakat.

Penelitian ini menemukan bahwa religiusitas memberikan pengaruh positif dan signifikan terhadap persepsi keamanan penganut agama Islam, Protestan, Katolik dan Hindu namun memberikan pengaruh negatif bagi penganut agama Budha. Hal tersebut dikarenakan toleransi keberagamaan hanya hidup di antara agama-agama mayoritas saja sehingga penganut agama mayoritas yang religius merasa semakin aman tetapi hal tersebut berlaku sebaliknya bagi penganut agama minoritas. Sedangkan kegiatan spiritual juga berpengaruh positif terhadap persepsi keamanan agama Islam dan Hindu, tetapi memberikan pengaruh negatif bagi para penganut Protestan, Katolik dan Budha. Hasil tersebut dikarenakan bahwa Islam sebagai mayoritas tentu akan cenderung merasa lebih aman dalam beribadah, sedangkan keberadaan agama Hindu terpusat di Pulau Bali sehingga lingkungannya relatif lebih aman bagi para penganutnya. Sedangkan fenomena terorisme dan pengeboman kerapkali terjadi pada rumah ibadah umat Protestan dan Katolik sehingga keduanya merasa terancam ketika hendak melakukan kegiatan spiritual. Sebagai yang paling minoritas, Budha ditemukan sebagai agama dengan penganut yang merasa kurang aman dalam melakukan kegiatan spiritual. Sehingga keberadaan Budha relatif kurang aman di Indonesia. Hal tersebut membuktikan bahwa aman dan tidaknya seorang individu di Indonesia tidak hanya ditentukan dari aspek religiusitas namun juga aspek mayoritasminoritas.

Dikarenakan rasa aman merupakan kebutuhan setiap individu dalam hidup di tengah masyarakat yang beragam, maka diperlukan adanya peningkatan rasa toleransi terhadap keyakinan dan cara beribadah lintas agama untuk menciptakan kerukunan umat beragama yang dapat dilakukan melalui bangku pendidikan dan literasi. Selain itu, juga diperlukan adanya penekanan ajaran agama bahwa religiusitas bukan hanya mencakup ketaatan beribadah kepada Tuhan namun juga menjaga stabilitas lingkungan sosial dengan menghargai perbedaan dalam kehidupan oleh para tokoh agama.

\section{Daftar Pustaka}

Abd. Aziz, I. (2018). Transformasi Perilaku Masyarakat Beragama Dalam Kabupaten Batanghari Jambi. Kontekstualita. https://doi.org/10.30631/kontekstuali ta.v33i1.44

Abdullah, Z. (2018). An Analysis of Factors Affecting the Variation of GDP. Journal of Islamic Economics Lariba, 4(2), 1-21.

Abdullah, Z., \& Susamto, A. A. (2019). The Role of Investment-Based Islamic Crowdfunding for Halal MSMEs: Evidence from Indonesia. $A l$ Iqtishad: Jurnal Ilmu Ekonomi Syariah, 11(2), 289-302. 
https://doi.org/10.15408/aiq.v11i2.13 623

Cohen, A. B., \& Hill, P. C. (2007). Religion as culture: Religious individualism and collectivism among American catholics, jews, and protestants. Journal of Personality. https://doi.org/10.1111/j.14676494.2007.00454.x

Ellis, L. (1985). Religiosity and criminality: Evidence and Explanations of Complex Relationships. Sociological Perspectives. https://doi.org/10.2307/1389231

Ellis, L., \& Peterson, J. (1996). Crime and religion: An international comparison among thirteen industrial nations. Personality and Individual Differences.

https://doi.org/10.1016/01918869(96)00023-2

Evans, T. D., Cullen, F. T., Dunaway, R. G., \& Burton, V. S. (1995). Religion and Crime Reexamined: The Impact of Religion, Secular Controls, and Social Ecology on Adult Criminality. Criminology, 33(2), 195-224. https://doi.org/10.1111/j.17459125.1995.tb01176.x

Gaduh, A. (2012). Religion, Social Interactions , and Cooperative Attitudes: Evidence from Indonesia. Manuscript, Departements of Economics, University of Southern California, (March), 1-58.

Gearon, L. (2013). The counter terrorist classroom: Religion, education, and security. Religious Education. https://doi.org/10.1080/00344087.20 13.767660

Ghassem-Fachandi, P. (2006). Sacrifice, ahimsa, and vegetarianism: Pogrom at the deep end of non-violence.

Ghassem-Fachandi, P. (2010). Ahimsa, identification and sacrifice in the Gujarat pogrom. Social Anthropology. https://doi.org/10.1111/j.14698676.2010.00105.x

Johnson, B. R., Jang, S. J., Larson, D. B., \& De Li, S. (2001). Does adolescent religious commitment matter? A reexamination of the effects of religiosity on delinquency. Journal of Research in Crime and Delinquency. https://doi.org/10.1177/00224278010 38001002

Jubba, H., Pabbajah, M., Prasodjo, Z. H., \& Qodir, Z. (2019). The Future Relations between the Majority and Minority Religious Groups, Viewed from Indonesian Contemporary Perspective: A Case Study of the Coexistence of Muslims and the Towani Tolotang in Amparita, South Sulawesi. International Journal of Islamic Thought, 16, 13-23. https://doi.org/10.24035/ijit.16.2019. 002

Karyotis, G., \& Patrikios, S. (2010). Religion, securitization and anti-immigration attitudes: The case of greece. Journal of Peace Research. https://doi.org/10.1177/00223433093 50021

Kinnvall, C. (2004). Globalization and religious nationalism: Self, identity, and the search for ontological security. Political Psychology. https://doi.org/10.1111/j.14679221.2004.00396.x

Knudten, R. D., \& Knudten, M. S. (1971). Juvenile Delinquency, Crime, and Religion. Review of Religious Research. https://doi.org/10.2307/3510418

Kristianto, P. E. (2018). Persinggungan Agama dan Politik dalam Teror: Menuju Terbentuknya Teologi Spiritualitas Politik dalam Konteks Maraknya Terorisme di Indonesia. DUNAMIS: Jurnal Teologi dan Pendidikan Kristiani. https://doi.org/10.30648/dun.v3i1.17 5

Lim, C., \& Putnam, R. D. (2010). Religion, social networks, and life satisfaction. American Sociological Review. https://doi.org/10.1177/00031224103 86686

Lim, J. W., \& Yi, J. (2009). The effects of religiosity, spirituality, and social support on quality of life: A comparison between Korean American and Korean breast and gynecologic cancer survivors. Oncology Nursing Forum. https://doi.org/10.1188/09.ONF.699708 
MacDougall, J. M. (2005). Buddhist Buda or Buda Buddhists? Conversion, religious modernism and conflict in the minority Buda Sasak communities of New Order and post-Suharto Lombok. ProQuest Dissertations and Theses.

Malhotra, D. (2010). (When) are religious people nicer? Religious salience and the "Sunday Effect" on pro-social behavior. Judgment and Decision Making.

https://doi.org/10.2139/ssrn.1297275

Misbah, M. I., Yusuf, A., \& Wijaya, Y. (2019). Pendidikan Toleransi dalam Keluarga Beda Agama di Desa Kayukebek Kecamatan Tutur Kabupaten Pasuruan. Jurnal Mu'allim.

Mohammed, M. (2019). Religiosity and desistance from crime. Dalam The Architecture of Desistance. https://doi.org/10.4324/97804294618 04-11

Momtaz, Y. A., Hamid, T. A., Ibrahim, R., Yahaya, N., \& Chai, S. T. (2011). Moderating effect of religiosity on the relationship between social isolation and psychological well-being. Mental Health, Religion and Culture. https://doi.org/10.1080/13674676.20 10.497963

Monitor, D. M. (2002). Investigation into Bali blast moves forward; Indonesia's police Thursday announced they will call the leader of Jemaah Islamiyah for questioning. The Christian Science Monitor.

Pabbajah, M., Abdullah, I., Juhansar, \& Jubba, H. (2019). Contested Socioreligious Reality: An-Nadzir, a Non-mainstream Islamic Movement in Indonesia. The International Journal of Religion and Spirituality in Society, 9(2), 71-78. https://doi.org/10.18848/21548633/CGP/v09i02/71-78

Skaria, A. (2015). Ahimsa. Dalam Key Concepts in Modern Indian Studies (hlm. 5-7). https://doi.org/10.4324/97813157737 42-22

Souryal, S. S. (1987). The Religionization of a Society: The Continuing Application of Shariah Law in Saudi
Arabia. Journal for the Scientific Study of Religion. https://doi.org/10.2307/1387096

Stansfield, R., Mowen, T. J., O'Connor, T., \& Boman, J. H. (2017). The Role of Religious Support in Reentry: Evidence from the SVORI Data. Journal of Research in Crime and Delinquency. https://doi.org/10.1177/00224278166 57578

Stavrova, O., Fetchenhauer, D., \& Schlösser, T. (2013). Why are religious people happy? The effect of the social norm of religiosity across countries. Social Science Research. https://doi.org/10.1016/j.ssresearch.2 012.07.002

Strauss, J., Witoelar, F., \& Sikoki, B. (2016). The Fifth Wave of the Indonesia Family Life Survey: Overview and Field Report: Volume 1. The Fifth Wave of the Indonesia Family Life Survey: Overview and Field Report: Volume 1, I(March). https://doi.org/10.7249/wr1143.1

Tabrani, D. (2019). Familial terrorism: An anthropological analysis on familial suicide bombings in Surabaya, 13-14 may 2018. International Journal of Recent Technology and Engineering .

Toft, M. D. (2007). Getting religion? The puzzling case of Islam and civil war. International Security. https://doi.org/10.1162/isec.2007.31. 4.97

Utaberta, N. (2014). Interaksi Sosial Dan Kriminalitas Di Perumahan. Sinektika, 1(1), 189-192.

Vail, K. E., Arndt, J., \& Abdollahi, A. (2012). Exploring the Existential Function of Religion and Supernatural Agent Beliefs Among Christians, Muslims, Atheists, and Agnostics. Personality and Social Psychology Bulletin. https://doi.org/10.1177/01461672124 49361

Valpey, K. (2018). Hinduism: Animating samadhi-Rethinking animal- human relationships through yoga. Dalam The Routledge Handbook of Religion and Animal Ethics. https://doi.org/10.4324/97804294898 46 
Warr, M. (2017). Life-Course transitions and desistance from crime. Dalam The Termination of Criminal Careers (hlm. 447-480). https://doi.org/10.4324/97813150850 81-27

Widiani, D., \& Jiyanto, J. (2018). The Importance of Mother's Role in Preventing Children's Radicalism. YINYANG: Jurnal Studi Islam, Gender dan Anak. https://doi.org/10.24090/yinyang.v13 i1.2018.pp33-69

Widyaningrum, N., \& Yu, J. (2018). Tobacco Use Among the Adult Muslim Population in Indonesia: A Preliminary Study on Religion, Cultural, and Socioeconomic Factors. Journal of Drug Issues, 48(4), 676688.

https://doi.org/10.1177/00220426187 89491 